\title{
PEMBERIAN SENAM ANTIHIPERTENSI SEBAGAI UPAYA MENSTABILKAN TEKANAN DARAH: STUDI KASUS PADA KELUARGA BINAAN DI DESA KEMUNINGSARI LOR KECAMATAN PANTI KABUPATEN JEMBER
}

\author{
Misbakhul Anwari ${ }^{1}$, Rita Vidyawati ${ }^{2}$, Ropickhotus Salamah ${ }^{3}$, Mashila Refani ${ }^{4}$, \\ Nur Winingsih ${ }^{5}$, Dwi Yoga ${ }^{6}$, Rizka Inna ${ }^{7}$, Tantut Susanto ${ }^{8 *}$ \\ 1,2,3,4,5,6,7,8 Fakultas Keperawatan, Universitas Jember \\ Jl. Kalimantan No. 37 Kampus Tegal Boto Jember Telp./Fax. (0331) 323450 \\ *e-mail: tantut_s.psik@unej.ac.id
}

\begin{abstract}
ABSTRAK
Hipertensi merupakan penyakit tidak menular yang terjadi pada sistem kardiovaskuler dan memiliki angka mortalitas dan morbiditas yang tinggi. menurut WHO pada tahun 2020 Penyakit Tidak Menular (PTM) akan menyebabkan kematian sebesar $73 \%$ dan seluruh kesakitan di dunia sebesar 60\% (WHO, 2013). Hipertensi dapat diatasi dengan terapi farmakologis dan non farmakologis. Pola perilaku perlu untuk diperhatikan bagi seseorang yang mengalami hipertensi. Pola perilaku seperti pengaturan pola makan, kebiasaan tidur, dan teratur untuk berolahraga. Penelitian ini bertujuan untuk mengetahui pengaruh pola perilaku terhadap kestabilan tekanan darah pasien hipertensi. Sampel dalam penelitian ini adalah pasien kelolaan keperawatan keluarga yaitu Ny. Y yang mengalami hipertensi yang berada di Desa Kemuningsari Lor Kecamatan Panti Kabupaten Jember. Teknik pengambilan sampel dari penelitian ini berdasarkan pasien kelolaan dalam mata kuliah keperawatan keluarga. Hasil penelitian menunjukkan bahwa pola perilaku mempengaruhi kestabilan tekanan darah pada pasien hipertensi.

Kata kunci: Senam antihipertensi, Tekanan Darah
\end{abstract}

\section{PENDAHULUAN}

Hipertensi merupakan salah satu penyakit tidak menular yang menjadi masalah kesehatan yang serius baik di Indonesia maupun di Dunia. Hipertensi disebut sebagai silent killer atau pembunuh diam-diam, karena penderita hipertensi sering tidak menampakkan gejala. Salah satu tanda penyakit hipertensi adalah terjadinya peningkatan tekanan darah.

Prevalensi hipertensi di dunia diperkirakan sebesar 1 milyar jiwa dan hampir 7,1 juta kematian setiap tahunnya akibat hipertensi, atau sekitar $13 \%$ dari total kematian (Gusmira, 2012). Prevalensi di Indonesia dengan umur diatas 25 tahun adalah sebesar $8,3 \%$

dengan jumlah prevalensi laki-laki sebesar $12,2 \%$ dan perempuan $15,5 \%$. Berdasarkan hasil Riset Kesehatan Dasar Depkes (Riskesdes) 2013, sekitar 76\% kejadian hipertensi di masyarakat belum terdiagnosis. Hal ini didapat dari pengukuran tekanan darah pada usia 18 tahun ke aas ditemukan prevalensi hipertensi di Indonesia sebesar 31,7\% (Depkes RI, 2013). Dilihat dari sudut pandang epidemiologi, seseorang yang menderita hipertensi diperkirakan karena beberapa faktor seperti usia, jenis kelamin, genetik, obesitas, merokok, kurang aktivitas fisik, stress, dan asupan natrium berlebih (Babatsikou, 2010).

Fenomena hipertensi di Indonesia sebesar $9,3 \%$ yang terdiagnosa tenaga kesehatan atau sedang minum obat 9,4\% (Trihono, 2013) menunjukkan bahwa pasien hiertensi masih banyak menggunakan pengobatan dengan menggunakan pengobatan dengan cara terapi farmakologi. Selain terapi farmakologi, terapi nonfarmakologi yang dapat menurunkan tekanan darah adalah senam antihipertensi. 
Olahraga seperti senam antihipertensi mampu mendorong jantung bekerja secara optimal, dimana olahraga mampu meningkatkan kebutuhan energi oleh sel, jaringan dan organ tubuh, dimana akibatnya dapat meningkatkan aliran balik vena sehingga menyebabkan volume sekuncup yang akan lengsung meningkatkan curah jantung sehingga menyebabkan tekanan darah arteri meningkat, setelah tekanan darah arteri meningkat maka dapat memberikan dampak pada penurunan aktivitas pernafasan dan otot rangka yang menyebabkan saraf simpatis menurun, setelah itu akan memnyebabkan kecepatan denyut jantung menurun, volume sekuncup menurun, vasodilatasi arteriol vena, karena penurunan ini mengakibatkan penurunan curah jantung dan penurunan resistensi perifer total, sehingga terjadinya penurunan tekanan darah (Sherwood, 2005).

Senam antihipertensi merupakan olahraga yang salah satu bertujuan untuk meningkatkan aliran darah dan pasokan oksigen kedalam otot-otot jantung dan rangka yang aktif khususnya terhadap otot jantung. Menurut Mahardani (2010) mengatakan bahwa dengan senam atau berolah raga kebutuhan oksigen dalam sel akan meningkat untuk proses pembentukan energi, sehingga terjadi peningkatan denyut jantung, menyebabkan terjadinya curah jantung dan isi sekuncup bertambah. Hal ini menyebabkan tekanan darah menngkat. Setelah beristirahat pembuluh darah akan berdilatasi atau meregang, dan aliran darah akan turun sementara waktu, sekitar 30-120 menit kemudian akan kembali pada tekanan darah sebelum senam. Jika melakukan olahraga rutin dan terus menerus, maka penurunan tekanan darah akan berlangsung lebih lama dan pembuluh darah akan lebih elastis. Mekanisme penurunan tekanan darah setelah berolahraga adalah karena olahraga dapat merilekskan pembuluh darah sehingga tekanan darah akan menurun.
Berdasarkan hasil pengkajian mahasiswa Program Studi Pendidikan Profesi Ners Universitas Jember pada tanggal 11 Mei di RW 5 - 8 Desa kemuningsari Lor berdasarkan sampel 101 KK didapatkan hasil distribusi penyakit sebanyak $14 \quad(13,9 \%)$ KK dengan hipertensi. Pengkajian 28 Mei 2018 terhadap Ny. Y diketahui bahwa saat ini klien mengatakan darahnya sering naik turun tidak stabil. Ketika darahnya naik pasien akan mengalami sakit kepala bagian belakang dan mengatakan sulit tidur. Klien mengatakan ketika darah tinggi akan tidur dan jika sudah tidak tahan dengan sakitnya baru memeriksakan kondisinya ke pelayanan kesehatan. Sehari-hari klien adalah seorang ibu rumah tangga yang sebagian besar waktunya dihabiskan untuk berada di rumah. Banyak waktu yang dihabiskan untuk bersantai selama dirumah. Keluarga Ny. Y merupakan keluarga yang saling peduli dengan anggota keluarganya. Keluarga selalu berada di sisi $\mathrm{Ny}$. $\mathrm{Y}$ dalam keadaan apapun. Ketika Ny. Y sakit, maka akan dibawa ke pelayanan kesehatan terdekat. Berdasarkan analisa situasi dan kondisi maka Mahasiswa Program Profesi Ners Universitas Jember telah melatih keluarga dan Ny. Y untuk melakukan senam antihipertensi.

\section{METODE}

Penelitian ini adalah penelitian studi kasus dengan pendekatan kuantitatif dan kualitatif pada keluarga kelolaan yaitu Ny. Y yang mengalami hipertensi, sebelum dilakukan intervensi peneliti melakukan penilaian pretest dan akan melakukan posttest setelah akhir intervensi pada keluarga kelolaan selama 14 pertemuan. Senam hipertensi merupakan aktifitas fisik yang dilakukan berupa gerakan senam khusus penderita hipertensi yang dilakukan selama 30 menit dengan tahapan 5 menit latihan pemanasan, 20 menit gerakan peralihan dan 5 menit gerakan pendinginan dengan frekuensi 2 kali dalam satu minggu. senam ini 
bertujuan untuk melancarkan peredaran darah dan meregangkan otot kaku pada klien yang mengalami hipertensi. Pengumpulan data menggunakan Sphygmomanometer terkalibrasi.

\section{HASIL DAN PEMBAHASAN}

Karakteristik Responden

Tabel 1. Karakteristik Responden

\begin{tabular}{lcc}
\hline Karakteristik & $\mathrm{n}$ & $\%$ \\
\hline Jenis Kelamin & & \\
\hline Perempuan & 1 & 100 \\
\hline Umur & & \\
\hline 43 tahun & 1 & 100 \\
\hline
\end{tabular}

Tekanan Darah Klien

Table 2. Tekanan Darah Klien

\begin{tabular}{lcccc}
\hline Nilai Statistik & \multicolumn{2}{c}{ Pre test } & \multicolumn{2}{c}{ Post test } \\
\cline { 2 - 5 } & $\begin{array}{c}\text { Sisto } \\
1\end{array}$ & $\begin{array}{c}\text { Dias } \\
\text { tole }\end{array}$ & $\begin{array}{c}\text { Sisto } \\
1\end{array}$ & $\begin{array}{c}\text { Dias } \\
\text { tole }\end{array}$ \\
\hline Pertemuan 1 & 150 & 70 & 150 & 60 \\
\hline Pertemuan 2 & 140 & 80 & 130 & 80 \\
\hline Pertemuan 3 & 150 & 80 & 140 & 70 \\
\hline Pertemuan 4 & 140 & 70 & 130 & 70 \\
\hline Pertemuan 5 & 140 & 90 & 140 & 90 \\
\hline Pertemuan 6 & 130 & 70 & 130 & 80 \\
\hline Pertemuan 7 & 140 & 70 & 130 & 70 \\
\hline Pertemuan 8 & 140 & 80 & 140 & 70 \\
\hline Pertemuan 9 & 150 & 70 & 140 & 70 \\
\hline Pertemuan 10 & 140 & 80 & 140 & 70 \\
\hline Pertemuan 11 & 140 & 80 & 140 & 80 \\
\hline Pertemuan 12 & 130 & 70 & 130 & 80 \\
\hline Pertemuan 13 & 140 & 70 & 130 & 80 \\
\hline Pertemuan 14 & 130 & 80 & 130 & 70 \\
\hline Rata-rata & 140 & 75,7 & 135, & 74,3 \\
\hline
\end{tabular}

Nilai tendensi satistik tekanan darah klien pada awal (pre test) diperoleh rata-rata tekanan darah sistol sebesar 140 $\mathrm{mmHg}$, dan tekanan darah diastol 75,5 mmHg. Selanjutnya nilai tendensi statistik tekanan darah klien setelah intervensi (post test) diperoleh rata-rata tekanan darah sistol sebesar $135,8 \mathrm{mmHg}$ dan tekanan darah diastole sebesar 74,3 $\mathrm{mmHg}$.
Penurunan rata-rata tekanan darah sistol dan diastole pretest ke post test klien ditampilkan pada Grafik 1.

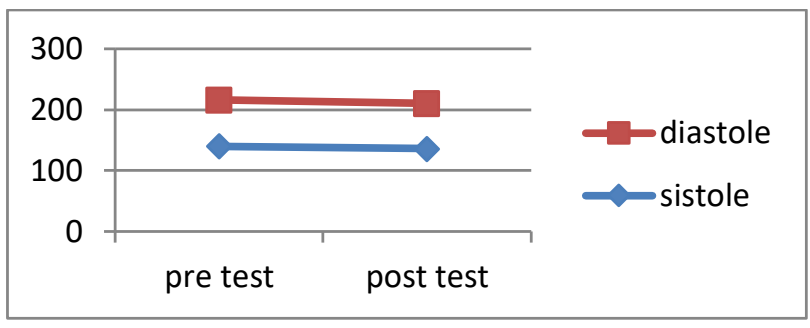

Gambar 1. Grafik Penurunan Rata-rata Tekanan Darah

Nilai rata-rata tekanan darah sistol pre test (140) lebih tinggi dibandingkan raa-rata tekanan darah sistol post test $(135,8)$ sehingga disimpulkan pemberian intervensi senam hipertensi berpengaruh terhadap penurunan tekanan darah sistole klien. Nilai rata-rata tekanan darah diatole pre test $(75,7)$ lebih tinggi dibandingkan rata-rata tekanan darah diastole post test (74,3) sehingga disimpulkan pemberian intervensi senam hipertensi berpengaruh terhadap penurunan tekanan darah diastole klien.

\section{KESIMPULAN}

Berdasarkan dari hasil pembahasan, dapat disimpulkan bahwa klien tekanan darah klien sebelum pemberian intervensi dengan rata-rata nilai pre test sistole $140 \mathrm{mmHg}$ termasuk dalamklasifikasi stadium 1 dan diastole rata-rata 75,5 termasuk dalam klasifikasi normal. Tekanan darah klien setelah pemberian intervensi senam antihipertensi memiliki nilai rata-rata sistol sebesar 135,8 termasuk dalam klasifikasi prehipertensi dan nilai rata-rata diastole sebesar 74,3 termasuk dalam klasifikasi normal. Terdapat pengaruh senam antihipertensi terhadap tekanan darah klien di Desa Kemuningsari Lor Kecamatan Panti Kabupaten Jember.

\section{KEPUSTAKAAN}


Departemen Kesehatan Republik Indonesia., 2013, Profil Kesehatan Indonesia 2013, Departemen Kesehatan Republik Indonesia, Jakarta.

Gusmira, S., 2012, Evaluasi Penggunaan Antihipertensi Konvensional dan Kombinasi Konvensional Bahan Alam pada Pasien Hipertensi di Puskesmas Wilayah Depok, Makara, Kesehatan, Vol. 16, NO. 2. 77-83.

Kemenkes RI, 2013, Buletin Jendela Data dan Informasi Kesehatan, Kemenkes RI, Jakarta.

Komnas Lansia., 2010, Profil Penduduk Lanjut Usia 2009, Jakarta.

Mahardani, N.M.A.F., 2010, Pengaruh Senam Jantung Sehat terhadap Penurunan Tekanan Darah pada Penderita Hipertensi di klub Jantung Sehat Klinik Kardiovaskuler Rumah Sakit Hospital Cinere tahun 2010.

Riset Kesehatan Dasar (Riskesdas)., 2013, Kementrian Kesehatan RI, Badan Penelitian dan Pengembangan Kesehatan Kementrian Kesehatan RI, Jakarta.

Sherwood, L., 2005, Fisiologi kedokteran:dari Sel ke Sistem, EGC, Jakarta. 